\title{
Evaluation of Seed Bank in Three Age-Sequences of Arable Land within a Biosphere Reserve in Southwestern Nigeria
}

\author{
Uzoma Darlington Chima (Corresponding author) \\ Department of Forestry and Wildlife Management, \\ Faculty of Agriculture, University of Port Harcourt, Nigeria \\ Tel: 234-803-812-1887 E-mail: uzoma.chima@uniport.edu.ng
}

\begin{abstract}
Moses Oladepo Adedire
Department of Forestry and Wildlife Management,

College of Environmental Resources Management,

Federal University of Agriculture, Abeokuta, Nigeria

E-mail: depodire@yahoo.com
\end{abstract}

Adegboyega Michael Aduradola

Department of Forestry and Wildlife Management,

College of Environmental Resources Management,

Federal University of Agriculture, Abeokuta, Nigeria

E-mail: amaduradola@yahoo.com

David Adejare Agboola

Department of Biological Sciences,

College of Natural Sciences,

Federal University of Agriculture, Abeokuta, Nigeria

E-mail: jareagbo@yahoo.com 
Received: August 1, 2013

doi:10.5296/jee.v4i2.4083
Accepted: August 20, 2013

Published: October 25, 2013

URL: http://dx.doi.org/10.5296/jee.v4i2.4083

\begin{abstract}
Deforestation through shifting cultivation to feed the burgeoning population in Nigeria is intensifying without adequate knowledge of its impact on the self-repairing mechanisms of the forest ecosystem. This study examined soil seed bank in three age-sequences of arable land $-\mathrm{AF}_{1}, \mathrm{AF}_{2}$ and $\mathrm{AF}_{3}$, reflecting short, medium, and long period of cultivation respectively, at three depths $-0-5,5-10$ and $10-15 \mathrm{~cm}$. Herbaceous plants accounted for $85 \%$ percent of plant species in the seed bank at all age-sequences and soil depths. Species richness dropped sharply with increasing soil depth in all the age-sequences, and was highest in $\mathrm{AF}_{1}$, $\mathrm{AF}_{2}$, and $\mathrm{AF}_{3}$ at the $0-5 \mathrm{~cm}, 5-10 \mathrm{~cm}$, and $10-15 \mathrm{~cm}$ respectively. Seedling abundance decreased sharply with increasing soil depth in all age-sequences with $\mathrm{AF}_{3}$ having the highest number of seedlings at the $0-5 \mathrm{~cm}$ depth. Although $\mathrm{AF}_{3}$ had the highest seedling abundance at the $0-5 \mathrm{~cm}$ depth, seedling diversity in the age-sequences decreased with increasing length of cultivation with $\mathrm{AF}_{1}$ and $\mathrm{AF}_{3}$ having the highest and lowest diversity, respectively. Longer period of cultivation in $\mathrm{AF}_{3}$ seems to have favoured the populations of some seemingly more tolerant herbaceous species like Digitaria ternata and Spigelia anthelmia, both of which accounted for $75 \%$ of the total seedlings recorded at the $0-5 \mathrm{~cm}$ depth in $\mathrm{AF}_{3}$. Similarity in species composition between age-sequences was over $70 \%$ at the $0-5 \mathrm{~cm}$ depth but dropped to below $50 \%$ at lower depths, and between soil depths in the same age-sequence except between $\mathrm{AF}_{1} 10-15 \& \mathrm{AF}_{3} 10-15 \mathrm{~cm}$ and $\mathrm{AF}_{1} 5-10 \& \mathrm{AF}_{2} 5-10 \mathrm{~cm}$. The dominance of herbaceous plants in seed banks at $\mathrm{AF}_{1}, \mathrm{AF}_{2} \& \mathrm{AF}_{3}$, and the cutting of trees associated with shifting cultivation, imply that the native woody species have slim chance of regenerating in the farmlands. Therefore, a more eco-friendly farming system like agroforestry using indigenous species is recommended for the restoration of the native woody flora in the degraded farmlands.
\end{abstract}

Keywords: Length of cultivation, Soil depth, Seed bank, Species composition, Diversity, Forest regeneration 


\section{Introduction}

The burgeoning population in Nigeria and its associated pressure has led to indiscriminate use of land without much consideration on the ecological consequences. One of the reasons for the establishment of forest reserves in Southwestern Nigeria was to combat the structural and floristic degradation of tropical rainforests (Salami 1998); however, economic and demographic pressures are increasingly causing deforestation and unsustainable use of resources in these reserves.

In Omo biosphere reserve for instance, the original vegetation has changed remarkably due continuous human activities, mainly logging and farming, for almost a century. Ola-Adams (1999) reported that people were permitted to remain living within the $65 \mathrm{~km}^{2}$ of enclaves as at the time the reserve was established in 1925. However, the influx of settler farmers has continued to mount undue pressure on both the natural forest and available farmlands in the reserve. Fallow period has drastically reduced. As human populations continue to grow, land use intensity increases, and the negative effects of deforestation are likely to worsen (Chazdon 2003).

A study into the natural process which influence forest dynamics has shown that soil seed bank is one of the principal sources of recruitment for new individuals in the initial stages of forest succession (Butler and Chazdon 1998). Taketay (1996) observed that the transformation of natural landscapes accelerates biodiversity losses indirectly through the anthropogenic activities that degrade the self-repairing capacity of an ecosystem such as soil seed banks, soil fertility, etc. According to William-Linera (1993), the species richness and abundance in soil seed banks may provide information on the potential of a community for regeneration. In addition, the intensities of disturbance and pathways in natural regeneration as well as the strategies of establishment of individual species (Grime 1979, Degreef et al 2002) can be interpreted through soil seed bank analysis.

However, no study had been carried out in Omo Biosphere Reserve to ascertain the impact of length or period of arable cropping on the seed bank. Considering the importance of the seed bank in regeneration, succession and restoration of plant communities, this study examined the impact of length of cultivation on soil seed bank. Specifically, it evaluated species composition, abundance and diversity of seed bank in three age-sequences of arable land $\mathrm{AF}_{1}, \mathrm{AF}_{2}$ and $\mathrm{AF}_{3}$, reflecting short, medium, and long period of cultivation respectively, at different soil depths. It is hoped that the results obtained will be useful in predicting future successions and plant species adaptability to increasing human disturbance.

\section{Materials and Methods}

\subsection{Description of the Study Area}

Omo Biosphere Reserve is located between latitudes $6^{\circ} 35^{\prime}$ to $7^{\circ} 05^{\prime} \mathrm{N}$ and longitudes $4^{\circ} 19^{\prime}$ to $4^{\circ} 40^{\prime} \mathrm{E}$ in the South-west of Nigeria (Ojo 2004); about $135 \mathrm{~km}$ north-east of Lagos, about $120 \mathrm{~km}$ east of Abeokuta and about $80 \mathrm{~km}$ east of Ijebu Ode (Ola-Adams 1999). The reserve shares a common boundary in its northern part with two other forest reserves - Ago Owu and Shasha in Osun State. It also has a common boundary with Oluwa Forest Reserve in Ondo 
State (Karimu 1999); and covers 130,500 hectares of land (Ola-Adams 1999, Ojo 2004).

\subsection{Selection and Description of Study Sites}

Three chronosequences of arable land $-\mathrm{AF}_{1}, \mathrm{AF}_{2}$ and $\mathrm{AF}_{3}$ - reflecting short, medium and long period of cultivation respectively, were selected from around Mile 1 enclave in Area J4, for the study. Chronosequence $\mathrm{AF}_{1}\left(6^{\circ} 50^{\prime} 26.77^{\prime \prime} \mathrm{N}\right.$ and 4${ }^{\circ} 21^{\prime} 37.03 " \mathrm{E}$; Altitude: $\left.105 \mathrm{~m}\right)$ has been subjected to cultivation of crops including Manihot esculenta, Zea mays, and Dyscorea spp. since the past 12 years. Tree species observed on the farm include Tectona grandis, Nauclea diderrichii, Ceiba pentandra, Gmelina arborea, Elaeis guineensis, Terminalia superba, Albizia zygia, Ficus sp., and Alstonia boonei.

Chronosequence $\mathrm{AF}_{2}\left(6^{\circ} 50\right.$ '29.71"N and 4 21'37.61"E; Altitude: $\left.104 \mathrm{~m}\right)$ has been subjected to cultivation of crops including Manihot esculenta, Zea mays, and Dyscorea spp. since the past 22 years. Tree species present on the farm include Nauclea diderrichii, Albizia zygia, Anarcadium occidentalis, Uapaca guineensis, Gmelina arborea, Ceiba pentandra, Terminalia superba and Alstonia boonei.

Site $\mathrm{AF}_{3}\left(6^{\circ} 50^{\prime} 32.80^{\prime \prime} \mathrm{N}\right.$ and $4^{\circ} 21^{\prime} 38.85^{\prime \prime E}$; Altitude: $\left.102 \mathrm{~m}\right)$ has been subjected to cultivation of crops including Manihot esculenta, Zea mays, and Dyscorea spp. since the past 37 years. Few individuals of Nauclea diderrichii, Alstonia boonei, Elaeis guineensis, Ficus sp., and Milicia excelsa were observed on the farm. Figure 1 is the map of Omo Biosphere Reserve showing the study sites. 


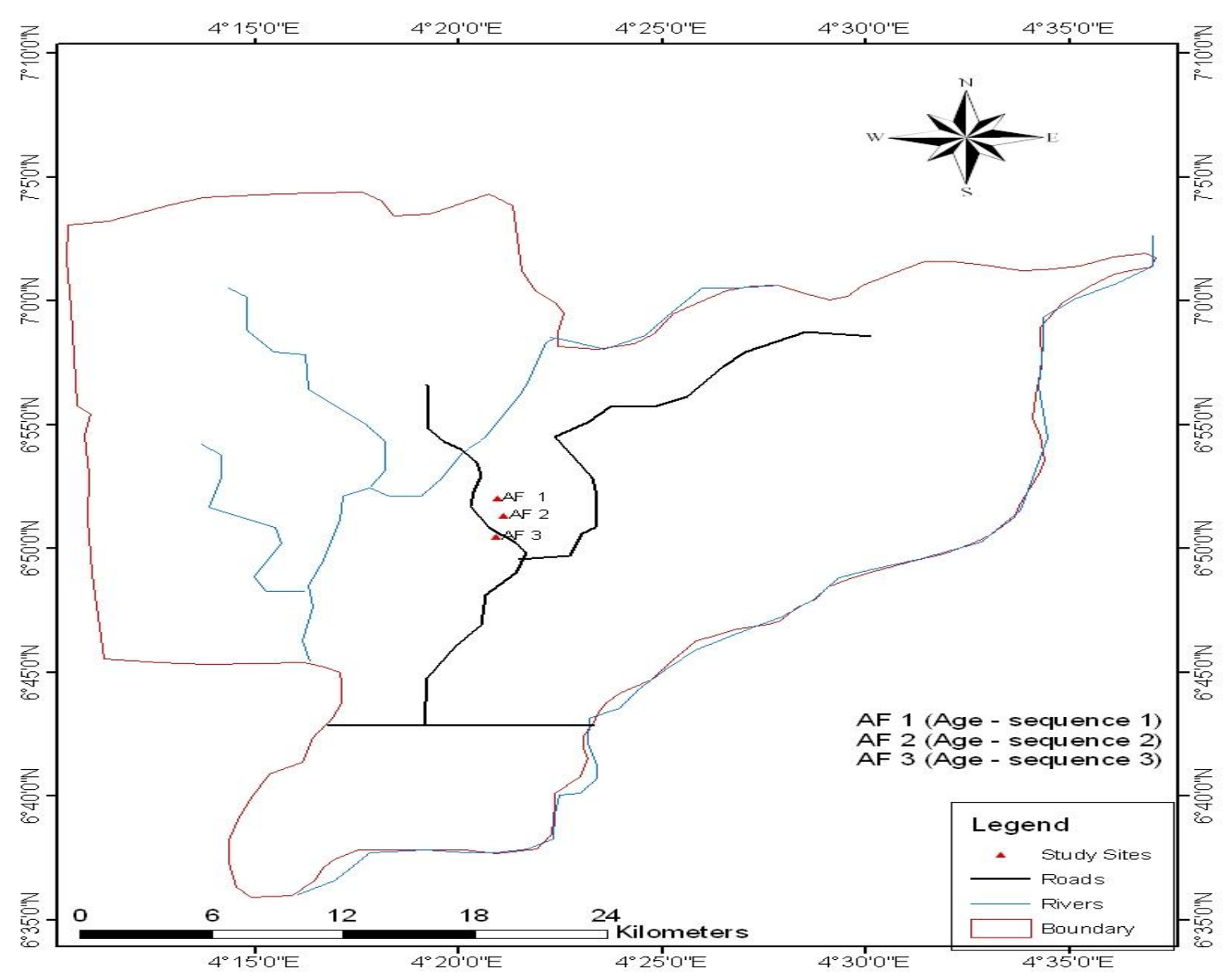

Figure 1. Map of Omo Biosphere Reserve showing the study sites

\subsection{Data Collection}

Five random plots, $2 \mathrm{~m} \times 2 \mathrm{~m}$, were marked out at each farmland. Three subplots $-20 \mathrm{~cm} \times$ $20 \mathrm{~cm}$, were also marked out in a triangular shape, at the centre of each plot. The rationale for taking subplots was to capture the spatial heterogeneity of soil seed distribution. Soil samples were removed from $0-5 \mathrm{~cm}, 5-10 \mathrm{~cm}$ and $10-15 \mathrm{~cm}$ soil layers in each subplot and bulked for corresponding soil layers in each farmland. The bulked sample for each farmland was divided into six equal parts, four of which were randomly selected for germination trials at the Forestry Research Institute of Nigeria (FRIN) Experimental Nursery. Soil samples were spread to a thickness of $3 \mathrm{~cm}$ on perforated plastic trays (diameter: $30 \mathrm{~cm}$ and depth: $3 \mathrm{~cm}$ ) that were kept moist continuously.

The seedling emergence method was used to assess the species composition and abundance of seed bank at the three farmlands. This method has been used by other workers (e.g. Senbeta and Taketay, 2001; Lemenih, 2004; Oke et al., 2007) to evaluate soil seed banks in different land use types. Emerging seedlings that are readily identifiable were counted, recorded and discarded on monthly basis. Seedlings that were difficult to identify were counted, labeled, transplanted and grown separately until they could be identified. After identification and counting of seedlings each month, soil samples were stirred to stimulate seed germination. This exercise continued until germination stopped. 


\subsection{Data Analysis}

\subsubsection{Seed Bank Species Diversity}

Shannon index of general diversity (Odum 1971) was used to measure the diversity of seed bank in each of the age-sequences of arable land.

Shannon index is expressed as:

$\mathrm{H}=-\sum_{i=1}^{s}$ pi $\log \mathrm{pi}$ Eqn. 1

Where

$\mathrm{pi}=$ proportion of individuals in the ith species

$\mathrm{s}=$ total number of species

\subsubsection{Similarity in Seed Bank Species Composition}

Sorensen's similarity index (SI) was used to measure similarity in seed bank species composition between age-sequences of arable land. In this study, Sorensen's similarity index was computed following Magurran (2004).

$\mathrm{SI}=\frac{2 a}{2 a+b+c}$ Eqn. 2

Where

$\mathrm{a}=$ number of species present in both age-sequences.

$b=$ number of species present in age-sequence 1 but absent in age-sequence 2 .

$\mathrm{c}=$ number of species present in age-sequence 2 but absent in age-sequence 1 .

\subsubsection{Soil Depth/Species Interaction}

Cluster analysis was performed using the PAleontological STatistics (PAST) software to show soil depth/plant species interaction, such that soil depths with more similar species were grouped into the same cluster while those with dissimilar species were grouped into different clusters. In performing the cluster analysis, Sorensen's similarity index was used to measure the ecological distances in species between soil depths.

\section{Results}

\subsection{Plant Species Composition}

Checklist of plant species that germinated from seed banks at different soil depths and age-sequences is presented in Table 1. Herbaceous plants represented 85 percent of the species. Only three woody species - Gmelina arborea, Chromolaena odorata, and Trema orientalis, were observed in the seed banks. 
Table 1. Species composition of seed banks at different sites and soil depths

\begin{tabular}{|c|c|c|c|c|c|}
\hline \multirow{2}{*}{$\begin{array}{c}\text { Soil } \\
\text { depth } \\
(\mathrm{cm})\end{array}$} & \multirow[t]{2}{*}{ Species } & \multirow[t]{2}{*}{ Family } & \multicolumn{3}{|c|}{ Population } \\
\hline & & & $\mathrm{AF}_{1}$ & $\mathrm{AF}_{2}$ & $\mathrm{AF}_{3}$ \\
\hline \multirow[t]{17}{*}{$0-5$} & Argeratum conyzoides & Asteraceae & 2 & 1 & 4 \\
\hline & Aspilia africana & Compositae & 2 & 0 & 2 \\
\hline & Asystasia gigantica & Acanthaceae & 4 & 1 & 1 \\
\hline & Borreria scabra & Rubiaceae & 1 & 2 & 4 \\
\hline & Calopogonium mисunoides & Fabaceae & 2 & 1 & 6 \\
\hline & Centrosema pubescence & $\begin{array}{l}\text { Leguminosae - } \\
\text { Papilinionaceae }\end{array}$ & 0 & 2 & 0 \\
\hline & Chromolaena odorata & Asteraceae & 2 & 1 & 3 \\
\hline & Digitaria ternata & Cyperaceae & 11 & 21 & 70 \\
\hline & Discorea sp. & Discoreaceae & 1 & 6 & 0 \\
\hline & Gmelina arborea & Verbenaceae & 7 & 0 & 0 \\
\hline & Mariscus alternifolius & Cyperaceae & 5 & 0 & 0 \\
\hline & Oplismenus burmannii & Poaceae & 5 & 4 & 3 \\
\hline & Peperomia pellucida & Piperaceae & 1 & 0 & 3 \\
\hline & Sida acuta & Malvaceae & 0 & 0 & 1 \\
\hline & Spigelia anthelmia & Loganiaceae & 4 & 6 & 14 \\
\hline & Solenostemon monostachyus & Labiatae & 1 & 0 & 0 \\
\hline & Vernonia cinerea & Asteraceae & 3 & 0 & 1 \\
\hline \multirow[t]{6}{*}{$5-10$} & Borreria scabra & Rubiaceae & 1 & 2 & 0 \\
\hline & Digitaria ternata & Cyperaceae & 0 & 1 & 6 \\
\hline & Oplismenus burmannii & Poaceae & 1 & 0 & 0 \\
\hline & Phyllanthus amarus & Euphorbiaceae & 0 & 0 & 1 \\
\hline & Spigelia anthelmia & Loganiaceae & 2 & 2 & 0 \\
\hline & Trema orientalis & Cannabaceae & 0 & 1 & 0 \\
\hline \multirow[t]{6}{*}{$10-15$} & Calopogonium mисипоides & Fabaceae & 1 & 0 & 1 \\
\hline & Chromonaela odorata & Asteraceae & 0 & 1 & 0 \\
\hline & Digitaria ternata & Cyperaceae & 1 & 0 & 1 \\
\hline & Euphorbia heterophylla & Euphorbiaceae & 0 & 0 & 1 \\
\hline & Oplismenus burmannii & Poaceae & 1 & 1 & 0 \\
\hline & Solenostemon monostachyus & Labiatae & 0 & 0 & 1 \\
\hline
\end{tabular}

\subsection{Species Richness and Seedling Abundance}

Species richness dropped sharply with increasing soil depth in all the age-sequences, and was highest in $\mathrm{AF}_{1}, \mathrm{AF}_{2}$, and $\mathrm{AF}_{3}$ at the $0-5 \mathrm{~cm}, 5-10 \mathrm{~cm}$, and $10-15 \mathrm{~cm}$ respectively (Figure 2). Seedling abundance also dropped sharply with increasing soil depth in all age-sequences with $\mathrm{AF}_{3}$ having the highest number of seedlings at the $0-5 \mathrm{~cm}$ depth (Figure 3 ). 


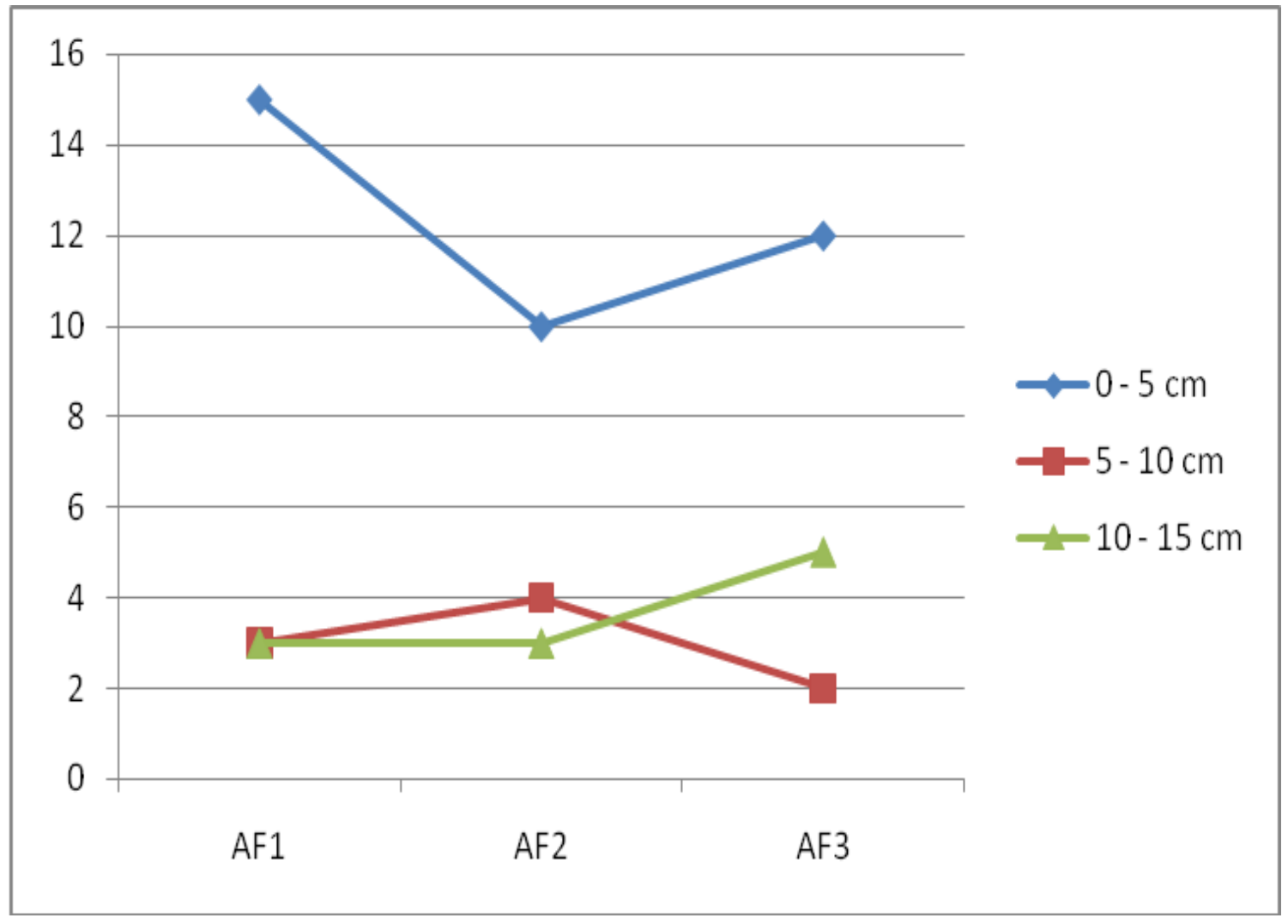

Figure 2. Seed bank species richness at different sites and soil depths

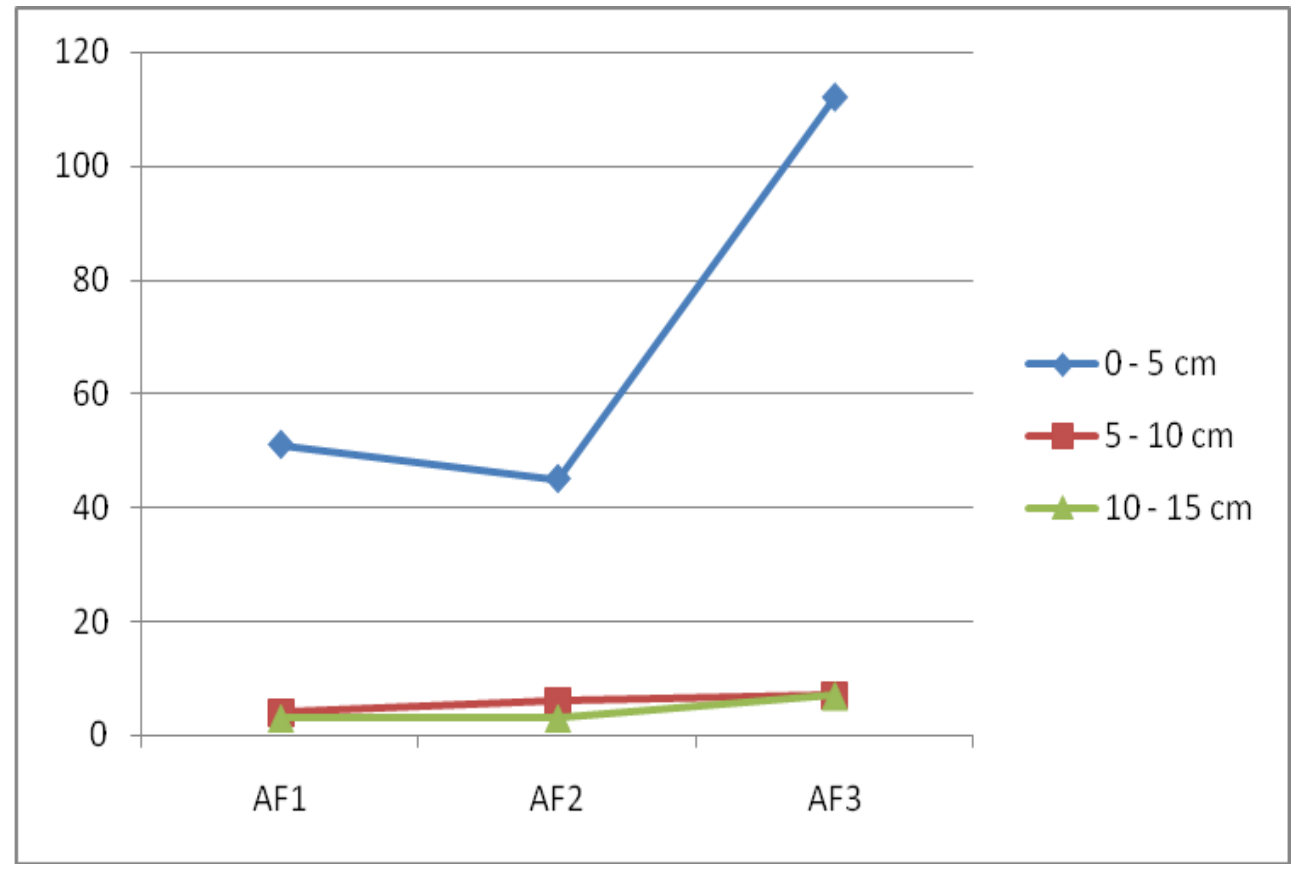

Figure 3. Seed bank seedling abundance at different sites and soil depths 


\subsection{Species Diversity and Similarity}

Species diversity was highest in $\mathrm{AF}_{1}$, followed by $\mathrm{AF}_{2}$ and $\mathrm{AF}_{3}$ respectively at the various soil depths except at the $5-10 \mathrm{~cm}$ depth where species diversity was highest in $\mathrm{AF}_{2}$ (Table 2). Similarity in species composition between age-sequences was over $70 \%$ at the $0-5 \mathrm{~cm}$ depth. However, similarity in species composition between age-sequences at lower depths, and between soil depths in the same age-sequence dropped below $50 \%$ except between $\mathrm{AF}_{1} 10-$ $15 \& \mathrm{AF}_{3} 10-15 \mathrm{~cm}$ and $\mathrm{AF}_{1} 5-10 \& \mathrm{AF}_{2} 5-10 \mathrm{~cm}$ (Table 3). Considering the similarity in species composition, different age-sequences clustered on the basis of soil depth except at $5-10 \mathrm{~cm}$ depth of $\mathrm{AF}_{3}$ and $10-15 \mathrm{~cm}$ depth of $\mathrm{AF}_{2}$ (Figure 4).

Table 2. Shannon diversity indices for different chronosequences and soil depths

\begin{tabular}{llll}
\hline Soil depth $(\mathrm{cm})$ & $\mathrm{AF}_{1}$ & $\mathrm{AF}_{2}$ & $\mathrm{AF}_{3}$ \\
\hline $0-5$ & 2.4410 & 1.7230 & 1.4380 \\
$5-10$ & 1.0400 & 1.3300 & 0.4101 \\
$10-15$ & 1.0990 & 0.6931 & 0.3860 \\
\hline
\end{tabular}

Table 3. Sorensen similarity indices for different sites and soil depths

\begin{tabular}{|c|c|c|c|c|c|c|c|c|c|}
\hline & $\begin{array}{l}\mathrm{AF}_{1} \\
0-5\end{array}$ & $\begin{array}{l}\mathrm{AF}_{1} \\
5-10\end{array}$ & $\begin{array}{l}\mathrm{AF}_{1} \\
10-15\end{array}$ & $\begin{array}{l}\mathrm{AF}_{2} \\
0-5\end{array}$ & $\begin{array}{l}\mathrm{AF}_{2} \\
5-10\end{array}$ & $\begin{array}{l}\mathrm{AF}_{2} \\
10-15\end{array}$ & $\begin{array}{l}\mathrm{AF}_{3} \\
0-5\end{array}$ & $\begin{array}{l}\mathrm{AF}_{3} \\
5-10\end{array}$ & $\begin{array}{l}\mathrm{AF}_{3} \\
10-15\end{array}$ \\
\hline $\mathrm{AF}_{1} 0-5$ & $*$ & 0.33 & 0.33 & 0.78 & 0.32 & 0.24 & 0.80 & 0.12 & 0.32 \\
\hline $\begin{array}{l}\mathrm{AF}_{1} \\
5-10\end{array}$ & & $*$ & 0.33 & 0.46 & 0.57 & 0.40 & 0.40 & 0.00 & 0.00 \\
\hline $\begin{array}{l}\mathrm{AF}_{1} \\
10-15\end{array}$ & & & $*$ & 0.46 & 0.29 & 0.40 & 0.40 & 0.40 & 0.57 \\
\hline $\mathrm{AF}_{2}$ 0-5 & & & & $*$ & 0.32 & 0.12 & 0.73 & 0.12 & 0.21 \\
\hline $\begin{array}{l}\mathrm{AF}_{2} \\
5-10\end{array}$ & & & & & $*$ & 0.00 & 0.38 & 0.33 & 0.25 \\
\hline $\begin{array}{l}\mathrm{AF}_{2} \\
10-15\end{array}$ & & & & & & $*$ & 0.29 & 0.00 & 0.00 \\
\hline $\mathrm{AF}_{3} 0-5$ & & & & & & & $*$ & 0.14 & 0.25 \\
\hline $\begin{array}{l}\mathrm{AF}_{3} \\
5-10\end{array}$ & & & & & & & & $*$ & 0.33 \\
\hline $\begin{array}{l}\mathrm{AF}_{3} \\
10-15\end{array}$ & & & & & & & & & $*$ \\
\hline
\end{tabular}




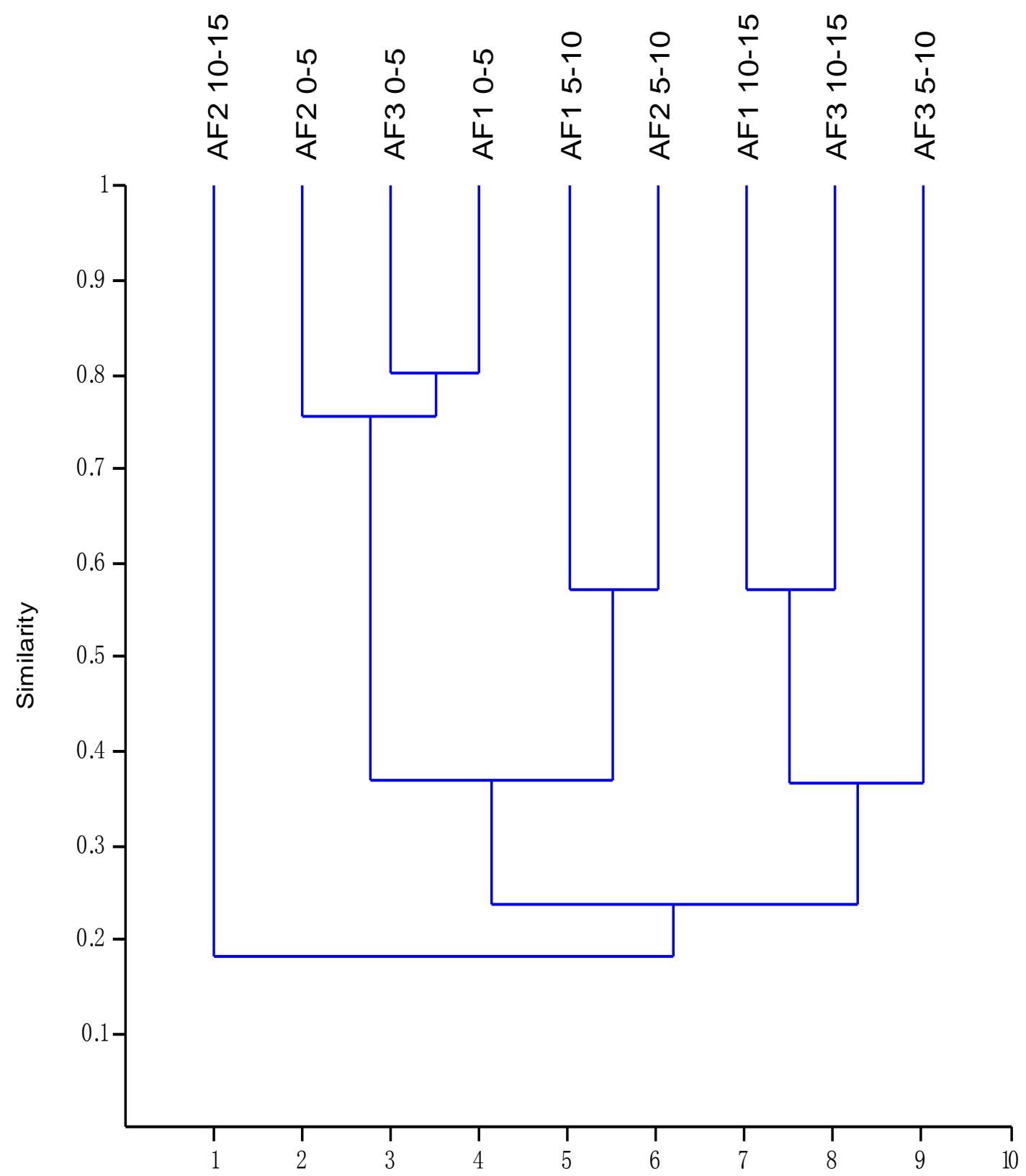

Figure 4. *Cluster dendogram showing within-site and between-site depth-plant species interactions

*Dendogram based on Sorensen's similarity index (Table 3)

\section{Discussion}

Both seedling abundance and species richness decreased with increasing soil depth in all the age-sequences of arable land, with the $0-5 \mathrm{~cm}$ soil depth accounting for over $80 \%$ of the total seedlings that emerged. Senbeta and Teketay (2002) equally observed that the number of seeds in the soil showed similar vertical distribution in almost all plantation stands and the adjacent forests studied, with the highest number of species and densities of seeds in the upper three centimeters of soil, and a gradual decreasing number of species and densities of 
seeds with increasing soil depth. However, there were marked differences among the age-sequences and soil depths with respect to seedling abundance and species diversity.

Despite the fact that $\mathrm{AF}_{3}$ had the highest seedling abundance at the $0-5 \mathrm{~cm}$ depth, seedling diversity in the age-sequences decreased with increasing length or period of cultivation with $\mathrm{AF}_{1}$ and $\mathrm{AF}_{3}$ having the highest and lowest diversity, respectively. It appears that longer period of cultivation in $\mathrm{AF}_{3}$ has favoured the populations of some seemingly more tolerant herbaceous species like Digitaria ternata and Spigelia anthelmia, both of which accounted for $75 \%$ of the total seedlings recorded at the $0-5 \mathrm{~cm}$ depth in $\mathrm{AF}_{3}$. The abundance of both species was also found to have increased with increasing period of cultivation at the $0-5 \mathrm{~cm}$ depth. Although, Oplismenus burmanii was found in all age-sequences, its abundance decreased slightly with increasing period of cultivation.

Disturbance of the original forest (through logging, slashing and burning, etc.) usually eliminates the seed bank of rain forest species (Guevara et al., 2005). Agricultural use and pasture management (weeding, ploughing, grazing, etc.) decrease the seed density of the pioneer tree species linked to forest gap colonization, and favour the growth of secondary weeds (Dalling and Denslow, 1998; Kellman 1980). We also observed that seed bank in all the age-sequences studied were dominated by herbaceous plants irrespective of the length of cultivation.

Species composition of the various age-sequences, seem not to have been affected by the length of cultivation like species diversity. For instance, $\mathrm{AF}_{1}$ and $\mathrm{AF}_{3}$ were slightly more similar in species composition than with $\mathrm{AF}_{2}$. The clustering pattern of the three age-sequences in relation to their species composition showed closer association for separate soil depths except at the 5-10 cm depth of $\mathrm{AF}_{3}$ and $10-15 \mathrm{~cm}$ depth of $\mathrm{AF}_{2}$. The plant species from the $5-10 \mathrm{~cm}$ seed bank in $\mathrm{AF}_{3}$ were more similar to those of the $10-15 \mathrm{~cm}$ in $\mathrm{AF}_{1}$ and $\mathrm{AF}_{3}$, while those of the $10-15 \mathrm{~cm}$ in $\mathrm{AF}_{2}$ were far apart from the others. However, the reasons for these deviations cannot be explained.

The importance of this study with respect to the impact of land cultivation on the regeneration potentials of the native woody flora in the reserve cannot be over-emphasized. The fact that herbaceous plants constitute $85 \%$ of the plants that germinated from the seed banks in all the age-sequences and soil depths means that the native woody species have very slim chances of regenerating in the farmlands. To make the matter worse is the fact that indiscriminate logging and shifting agriculture in the reserve are impacting negatively on the populations of tree and animal species that would have provided alternative means of regeneration through seed rain and seed dispersal respectively. Therefore, a more eco-friendly farming system like agroforestry using indigenous species is recommended for the restoration of the native woody flora in the degraded farmlands.

\section{Conclusion}

Seed bank in all the farmlands were dominated by herbaceous plants irrespective of the length of cultivation. This suggests that the herbaceous plants have better chances of regenerating on deforested lands subjected to arable cropping irrespective of the length or 
period of cultivation. However, longer period of cultivation impacted negatively on seed bank diversity. Also, species diversity, species richness, similarity in species composition and seedling abundance of seed banks decreased with increasing soil depths irrespective of the length of cultivation.

\section{References}

Butler, B. J., \& Chazdon, R. L. (1998). Species richness, spatial variation and abundance of the soil seed bank of a secondary tropical rain forest. Biotropica, 30, 214-222. http://dx.doi.org/10.1111/j.1744-7429.1998.tb00056.x

Chazdon, R. L. (2003). Tropical forest recovery: Legacies of human impact and natural disturbances. Prospect. Plant Ecol., 6, 51-71. http://dx.doi.org/10.1078/1433-8319-00042

Dalling, J. W., \& Denslow, J. S. (1998). Soil seed bank composition along a forest chronosequence in seasonally moist tropical forest, Panama. Journal of Vegetation Science, 9, 669 - 678. http://dx.doi.org/10.2307/3237285

Degreef, J., Rocha, O.J., Vanderborght, T. „\& Baudoin. J-P (2002). Soil seed bank and seed dormancy in wild populations of lima bean (Fabaceae); Considerations for in situ and ex situ conservation. Amer. J. Bo., 89, 1644-1650. http://dx.doi.org/10.3732/ajb.89.10.1644

Grime, J. P. (1979). Plant Strategies and Vegetation Processes. Chichester, U.K.: John Wiley \& Sons.

Guevara, S., Moreno-Casasola, P., \& Sanchez-Rios, G. (2005). Soil seed banks in the tropical agricultural fields of Los Tuxtlas, Mexico. Tropical Ecology, 46(2), 219-227

Karimu, S.A. (1999). The role of surrounding communities on the management of Omo Forest Reserve. Consultant Report for FORMECU, June 1999, 47.

Kellman, M.C. (1980). Geographic patterning in tropical weed communities and early secondary successions. Biotropica, 12, 34-39. http://dx.doi.org/10.2307/2388154

Lemenih, M. (2004). Effects of Land Use Changes on Soil Quality and Native Flora Degradation and Restoration in the Highlands of Ethiopia: Implications for Sustainable Land Management. Doctoral Thesis, Swedish University of Agricultural Sciences, Uppsala, June 2004.

Magurran, A. E. (2004). Measuring Biological Diversity. Oxford: Blackwell.

Odum, E. P. (1971). Fundamentals of Ecology. Philadephia: W.B. Saunders Company.

Ojo, L. O. (2004). The fate of a tropical rainforest in Nigeria: Abeku sector of Omo Forest Reserve, Global Nest, 6(2), 116-130.

Oke, S.O., Ayanwale, T.O. and Isola, O.A. (2007). Soil seedbank in four contrasting plantations in Ile-Ife area of Southwestern Nigeria. Res. J. Bot., 2, 13-22. http://dx.doi.org/10.3923/rjb.2007.13.22 


\section{Macrothink}

Journal of Environment and Ecology

ISSN 2157-6092 2013, Vol. 4, No. 2

Ola-Adams, B. A. (1999). Biodiversity Inventory of Omo Biosphere Reserve, Nigeria. Country Report on Biosphere Reserves for Biodiversity Conservation and Sustainable Development in Anglophone Africa (BRAAF) Project. 351pp.

Salami, A. T. (1998). Vegetation modification and man-induced environmental change in rural southwestern Nigeria. Agriculture, Ecosystems and Environment, 70, 159-167. http://dx.doi.org/10.1016/S0167-8809(98)00126-1

Senbeta, F. and Taketay, D. (2001). Regeneration of indigenous woody species under the canopies of tree plantations in Central Ethiopia, Tropical Ecology, 42(2), 175-185.

Senbeta, F. and Taketay, D. (2002). Soil seed banks in plantations and adjacent natural dry Afromontane forests of central and southern Ethiopia. Tropical Ecology, 43(2), 229-242.

Teketay, D. (1996). Seed Ecology and Regeneration in dry Afromontane Forests of Ethiopia. Doctoral Thesis, Swedish University of Agricultural Sciences, Umea, 36p + 5 Appendces.

Williams-Linera, G. (1993). Soil seed bank in four low mountain forests of Mexico. J. Trop. Ecol., 9, 321-337. http://dx.doi.org/10.1017/S0266467400007379 